\title{
The Construction of Long-term Mechanism of School-Enterprise Cooperation under the Background of Local Undergraduate Colleges' Transformation
}

\author{
Xiuping Li \\ Wuhan Donghu University, Wuhan City, Hubei Province, 430212, China
}

Keywords: Local Undergraduate Course; Transformation; School-enterprise Cooperation; Long-term Mechanism

\begin{abstract}
Local colleges and universities should require students to learn relevant theoretical knowledge systematically, and to master certain practical operation ability, so as to transmit applied talents with certain practical working ability to the society. The focal point of the local undergraduate talent training goal is to emphasize the application, and to emphasize the integration of knowledge and action. The mode of cooperation between schools and enterprises is the inevitable choice to achieve this goal. Based on the author's learning and practical experience, this paper first analyzed the current situation of the cooperation mode of local undergraduate colleges and universities, and then put forward the construction strategies of the long-term mechanism of university-enterprise cooperation in local colleges and universities under the background of transformation and development.
\end{abstract}

\section{Introduction}

Institutions of higher learning pursue social benefits and enterprises pursue economic benefits. How can achieve the unity of the objectives of both the school and the enterprise? The most basic point is to find out the common interests of both the school and the enterprise, and to realize the complementary advantages and cooperation between the school and the enterprise. Some local colleges and universities break away from the needs of economic and social development in terms of orientation and thinking of running a university, such as specialty setting, course materials, talent training structure and training mode, which are out of line with the actual and innovative practice of industrial development, so the difficulty of recruiting students appears in colleges and universities. In order to solve the contradiction between talent training and the demand for economic development, we must strengthen the top-level design, carry out the reform of the classification of higher education, and solve the problem of the orientation of running schools in colleges and universities to guide these colleges and universities to take the road of integration with local economic and social development and industrial development, to enhance the ability of local colleges and universities to serve the regional economic and social development. Microscopically, colleges and universities should set out from their own internal motive force and connotation construction, condense their own characteristics and improve their competitiveness.

\section{The Current Situation of the Cooperation Mode of Local Undergraduate Colleges and Universities}

\subsection{The connotation of school-to-Enterprise cooperation model in local undergraduate colleges and universities}

The main goal of local colleges and universities is to train applied professionals with both professional knowledge and practical ability for both society and enterprises to meet the needs of college students' employment and enterprise applied technical talents, thus promoting the further development of social economy. In order to achieve these goals, the school-enterprise cooperation model came into being. The mode of cooperation between local colleges and universities refers to the all-round cooperation between universities and enterprises. Colleges and universities make use 
of the financial and intellectual support provided by enterprises and provide opportunities for students' training and practice to meet the needs of enterprises and society and train applied professionals, so as to achieve the win-win goal.

\subsection{Problems existing in the mode of school-to-Enterprise cooperation in local colleges and universities}

At present, although the cooperation mode of local undergraduate colleges and universities has made some achievements, there are still many problems in its concrete practice, which will be discussed in detail below. (1) Lack of a correct understanding of the mode of cooperation between schools and enterprises. Relevant departments, schools and enterprises lack a correct understanding of the mode of cooperation between schools and enterprises, and have not yet realized that its importance is the most important issue in the application of the mode of cooperation between schools and enterprises in practice. At the present stage, the cooperation mode of school and enterprise is mainly led by the local education department, and undergraduate colleges and universities are the main implementers, and enterprises and government departments only passively cooperate with each other. In such an environment, the it lacks the incentive to the enterprise, and the enterprise only takes the economic benefit it can obtain as the measure standard to participate in the cooperation mode of the school and enterprise, thus, it lacks the correct understanding of the cooperation mode of the school and enterprise, and it is difficult to arouse its enthusiasm and initiative. (2) Lack of corresponding policies and regulations and management mechanism. At present, there is a lack of concrete and detailed relevant policies and regulations in the cooperation mode of local undergraduate colleges and universities, and many related policies often have only guiding significance and lack of clear division of rights and obligations. Moreover, due to the lack of corresponding policies and regulations and management mechanism, education departments, undergraduate colleges and enterprises are doing their own work, so it is difficult to form a unified and complete management mechanism. In addition, there is no clear supervision, evaluation and examination mechanism at the present stage. The cooperation between enterprises and schools is often superficial and difficult to restrain each other, which makes it difficult to achieve the desired results. (3) Operation mechanism and personnel training mode and enterprise demand do not adapt. On the one hand, because some undergraduate students lack the experience of life and the motivation to struggle, and because of the lack of funds and other problems, the cultivation of students needs longer time and energy. On the other hand, because of the cost, the enterprises in the cooperation mode of school and enterprise need more energy and time than the mature and experienced employees. Therefore, although the enterprise signs the agreement with the school under certain pressure, it becomes the formality, so it does not really invest in the model.

\section{The Construction Strategies of the Long-term Mechanism of School-Enterprise Cooperation in Local undergraduate Colleges and Universities in the Context of Transformation and Development}

\subsection{To constructs the running ecology of the long-term cooperation mechanism of local universities and enterprises to ensure the implementation of the policy}

Macroscopically, we should set up a "local government, trade association, enterprise group, school ecological" mode, which is led by the provincial government and responsible by the education department. After making clear the orientation of running a school and cultivating talents, the school should cooperate with the trade association and enterprise group, and form the ecological mode of "sharing, harmonious and developing" by relying on the strength of the industry to run a school. On the middle level, we should set up the cooperation committee and the industry and research committee for the characteristic development of the college. According to the professional chain group, the secondary branch or department should build the cooperation platform of the school and enterprise, and the secondary school or department should carry out the specific cooperation with different industries with their own characteristics. Microscopically, the concrete 
cooperation content, for example, the revision talent training plan, the joint research and development technology, the lecture, the academic exchange, the double teacher training and so on. In accordance with the regional economic development, the local undergraduate colleges and universities should pay close attention to the relevant preferential policies and consult with the cooperative enterprises in the ecological environment under the long-term mechanism of school-enterprise cooperation to make full use of all encouragement policies. In this way, the talents trained in the school will meet the needs of the enterprise, thus reducing the cost of human resources of the enterprise, promoting the healthy development of the enterprise, and then contributing to the transformation and development of the economic structure.

\subsection{The long-term mechanism of cooperation between local undergraduate schools and enterprises will realize the maximization of the interests of all parties}

The main interests participating in the cooperation between universities and enterprises in local universities could maximize the benefits by taking advantage of policy factors, market changes, and stakeholder development needs. Through the establishment of a local school-enterprise cooperation alliance platform, local governments, in accordance with the development of the industry and the characteristics of the various universities in the region, outline and build bridges between schools, enterprises and industries to form channels for implementing preferential policies of the state or the local authorities. Establish interworking mechanism, and adjust the demand of talents and the cooperation mode and content according to the development of the industry. As a result, local colleges and universities can promote the employment rate and cultivate qualified talents to meet the needs of the market, and the cooperative enterprises can hire the talents or reserve talents needed by the enterprises in advance, which is conducive to the sustainable development of enterprises.

\subsection{Overall planning in the form of school-Enterprise cooperation council to realize the effect of synergetic management}

The school-enterprise cooperation council studies the problems, trends and development directions, new concepts and new policies in the cooperation between schools and enterprises. They can set up a resource bank for the enterprises that have been in school for a long time, the enterprises where the graduates are in the past, and the representative enterprises in the industry, so that long-term cooperation enterprises priority to apply to the post of outstanding graduates according to the college professional chain group classification management. Students can also promote the brand, service, products, and improve the reputation of the enterprise and the enthusiasm of students to participate in the school. At the same time, the establishment of the long-term mechanism of cooperation between schools and enterprises can shorten the training of new employees, save costs, reduce tax burden, and obtain financial subsidies.

\subsection{To build a dual course system and establish a dynamic adjustment mechanism by school leading and enterprise guidance}

Students are the bridge to maintain the cooperation between schools and enterprises. Now students are employees of the future enterprises, so the establishment of the long-term mechanism of school-enterprise cooperation must first let enterprises and schools participate in the cultivation of students. Based on the school ecology of the long-term mechanism of cooperation between school and enterprise, the two-track curriculum system should be undertaken by the teachers in charge of the school and accept the advice of the experts of the enterprise and industry association under the cooperation council of the school and enterprise, and design the curriculum system in a targeted way.

\subsection{Standardized management of vocational certificate and clear guiding standard of school-Enterprise cooperation}

The post ability standard is the goal of school and enterprise cooperation to educate people together. Since the State Council cancelled 319 vocational qualification certificates, in addition to 
those related to national security, personal safety, food safety and environmental safety, the State Council must have a job qualification certificate to take up the post. The qualifications of other industries allow the market to function, and the government is only responsible for services and regulation. So, the current occupation certificate issued by the industry can only be a proof of professional post ability, but not a qualification condition. Therefore, through extensive investigation by the trade association, a standardized professional certificate management is formed. It can provide guiding basis and talent training standard for the establishment of long-term cooperation mechanism of local undergraduate schools and enterprises.

\section{Summary}

One of the important contents of the transformation and development of local undergraduate colleges and universities is the cooperation between schools and enterprises. Many local colleges and universities have established various modes of cooperation between schools and enterprises, but in order to make the cooperation between school and enterprise produce certain effect and sustainable cooperation, it must be based on the establishment and continuous optimization of long-term mechanism. Based on the theory of university ecology, the theory of interest relation and the theory of cooperative management, this paper learned lessons from the successful experiences of foreign universities and enterprises, and put forward the measures to establish a long-term mechanism of cooperation between schools and enterprises from five aspects: policy support, overall planning, concrete implementation and so on, in order to achieve the development of talent training characteristics and meet the needs of the market for talent standards.

\section{Acknowledgement}

The 12th Five-Year Plan of Education Science in Hubei Province in 2015. Item number: 2015GB195

\section{References}

[1] Ma Zhen. A study on the long-term Mechanism of Cooperation between Colleges and Enterprises in Private Colleges and Universities in Shaanxi Province [J]. Modern educational equipment in China, 2017, (15): 61-63.

[2] Ma Zhen. Study on the long-term Mechanism of University-Enterprise Cooperation in Local Universities under the background of Transformation [J]. Economic research guide journal, 2016, (32): 149-151.

[3] Zhang Pei. Study on the Construction of long-term Mechanism of School-Enterprise Cooperation in higher Vocational Education [J]. Educational theory and practice, 2016, 36(06): 15-17.

[4] Qi Qiong. Study on the long-term Mechanism of higher Vocational School-Enterprise Cooperation [J]. Education and teaching forum, 2015, (18): 29-30.

[5] Lu Xin. An Analysis of the factors influencing the Construction of the Long-term Mechanism of School-Enterprise Cooperation [J]. Journal of Baotou Vocational and Technical College, 2012, 13(03): 54-56+62. 